Pengaruh Kualitas Produk Dan Kualitas Layanan...(Aris Dan Suyoto)

\title{
PENGARUH KUALITAS PRODUK DAN KUALITAS LAYANAN TERHADAP KEPUTUSAN KONSUMEN PADA RESTAURAN IGA BAKAR MAS GIRI PURWOKERTO
}

\author{
Aris Ginajar Kusuma Putra \\ Universitas Muhammadiyah Purwokerto \\ Suyoto \\ Universitas Muhammadiyah Purwokerto
}

\begin{abstract}
This study amied to investigate the effect of product quality and service quality in the restaurant ribs grilled Mas Giri Purwokerto throught testing either simultaneously or partially. The method used in the analiysis method used is multipele linear regression with the significant level $(\alpha)$ of lees than 0.05 .

These result indicate that the product quality and quality of service simultaneously affect coustemer satisfaction, product quality and service quality in partial satisfaction of the coustemer, with a significant value of 0,00 and 0,00 is less than 0,05 .
\end{abstract}

Keywords : Quality Products, Quality Service and Coustemer Satisfaction.

\section{PENDAHULUAN}

\section{a. Latar Belakang}

Masyarakat dengan aktifitas kerja yang padat membuat mereka memilih untuk memenuhi kebutuhan makan di tempat-tempat yang tersedia di dekat tempat bekerja atau direstaurant terdekat. Aktifitas ini membuat mereka tidak punya banyak waktu untuk melakukanya ditempat tinggal mereka, khususnya pada ibu rumah tangga yang bekerja atau menjadi wanita karie. Sehingga kesulitan dalam menjalankan aktifitas sebagai ibu rumah tangga yang harus menediakan makanan bagi keluarganya. Biasanya mereka berasal dari kalangan masyarakat menengah-atas, yang cendrung memilih makan diluar rumah dengan memilih restauran yang diinginkan. Selain cita rasa, menu yang diberikan, kenyamanan dan hiburan juga menjadi hal yang dipertimbangkanya untuk mendapat keupasan.

Salah satu restauran di Puwokerto yang cukup besar di kota Purwokerto yaitu restauran Iga Bakar Mas Giri yang terletak di Jl. Suharso sebelah timur GOR Purwokerto, yang menawarkan berbagai menu istimewa hasil olahan dari iga sapi. Retauran ini merupakan yang pertama di Purwokerto, yang menyajikan menu Iga Bakar yang berbeda dari restauran lainya.sekarang juga sudah ada beberapa restaurant yang menyajikan menu yang sama dengan rasa yang berbeda sebagai pesaing.

Melihat kenyataan ini semakin menarik topik dan fenomena serta penelitian yang dilakukan sebelumnya yang dilakukan oleh Rachmad Hidayat (2009) menenai pengaruh kualitas layana, kualitas produk, dan nilai nasabahterhadap keupasan dan loyalitas nasabah bank mandiri penelitian ini menujukan kesimpulan secara umum adalah sebuah model terintegrasi yang berisi hubungan antara kualitas layanan, kualitas produk, dan nilai bagi nasabah, dengan kepuasan dan loyalitas nasabah. (1). Kualitas Layanan berpengaruh langsung terhadap kepuasan nasabah. (2). Kualitas Produk berpengaruh secara langsung terhadap kepuasan nasabah. (3). Nilai Bagi nasabah berpengaruh langsung terhadap kepuasan nasabah. (4) . Kualitas Layanan berpengaruh tidak langsung terhadap loyalitas nasabah dengan diantarai oleh kepuasan nasabah. (5) . Kualitas Produk berpengaruh tidak langsung terhadap loyalitas nasabah dengan diantarai oleh kepuasan nasabah. (6) . Nilai Bagi nasabah berpengaruh langsung 
maupun tidak langsung terhadap loyalitas nasabah dengan diantarai oleh kepuasan nasabah. Variabel nilai bagi nasabah menujukan adanya pengaruh yang paling kuat dan dominan terhadap loyalitas nasabah jika dibandingkan dengan variabel lainnya (kualitas layanan, kualitas produk, dan kepuasan nasabah). Hal ini mengidentifikasikan bahwa nilai yang didapat nasabah seperti tercermin dalam manfaat yang diperoleh dan pengorbanan yang dikeluarkan dapat secara langsung maupun tidak langsung (dengan diantarai oleh kepuasan nasabah) berpengaruh terhadap lolaitas nasabah. Bedanya penelitian sebelumnya yang dilakukan oleh Rachmad Hidayat (2009) dengan penelitian ini pada pengaruh yang sangat kuat dan dominan yaitu kualitas produk, kualitas layanan dan kepuasan konsumen.

Berdasarkan hasil obeservasi yang dilakukan oleh peneliti dan wawancara dengan manager dan juga karyawan restauran Iga Bakar Mas Giri Purwokerto, diperoleh hasil yang memuaskan dengan tingkat pengunjung yang bertambah septiap harinya. Hal ini membuat peneliti ingin mengetahui pengaruh tingkat Kualitas Produk dan Kualitas Layanan terhadap Kepuasan Konsumen pada Restauran Iga Bakar Mas Giri Purwokerto.

Adapun tujuan penelitian ini sebagai berikut :

a. Untuk menganalisis pengaruh kualitas produk terhadap kepuasan pada restauran Iga Bakar Mas Giri.

b. Untuk mengetahui kualitas layanan terhadap Kepuasan Konsumen pada restauran Iga Bakar Mas Giri.

c. Untuk mengetahui pengaruh kualitas produk dan kualitas layanan terhadap kepuasan konsumen pada restauran Iga Bakar Mas Giri.

\section{b. Kerangka Pemikiran}

Dari kualitas produk yang diberikan diharapkan dapat memberikan kepuasan bagi pembeli, Hasil yang dirasakan oleh pembali yang mengalami kinerja sebuah perusahaan yang sesuali dengan harapannya disebut kepuasan konsumen (Kotler , 2000). Kuncinya adalah memenuhi harapan konsumen dengan prestasi perusahaan. Perusahaan yang cerdik mempunyai tujuan membuat gembira konsumen dengan hanya menajikan apa yang dapat mereka serahkan, kemudian menyerahkan lebih banyak dari yang mereka janjikan.

Selanjutnya Assauri (2003) menyatakan bahwa konsumen menilai mutu atau kualitas umumnyasetelah konsumen tersebut menerima jasa atau pelayanan itu dari suatu perusahaan tertentu. Mereka menilai mutu jasa atau pelayanan yang mereka terima dengan harapan mereka atas jasa atau pelayanan tersebut. Konsumen mempertimbangkan mutu jasa atau pelayanan tersebut dalam beberapa dimensi. Dimensi-dimensi dari jasa atau pelayanan yang didapat atau diterima konsumen, mereka nilai terhadap apa yang mereka harapkan atas dimensi tersebut.

Kesadaran akan kepuasan tersebut menyebabkan perusahaan untuk meningkatkan kualitas pelayanan dengan mempersepsikan bobot kepentingan serta tingkat kinerja dan kriteria pembelian yang berbeda dari setiap konsumen yang berbeda dari setiap konsumen yang diikuti dengan adanya upaya menggali informasi dari pasar.

Berdasarkan uraian diatas maka pengaruh kualitas produk dan kualitas layanan terhadap kepuasan konsumen pada Restauran Iga Bakar Mas Giri dapat digambarkan dalam kerangka pemikiran sebagai berikut: 


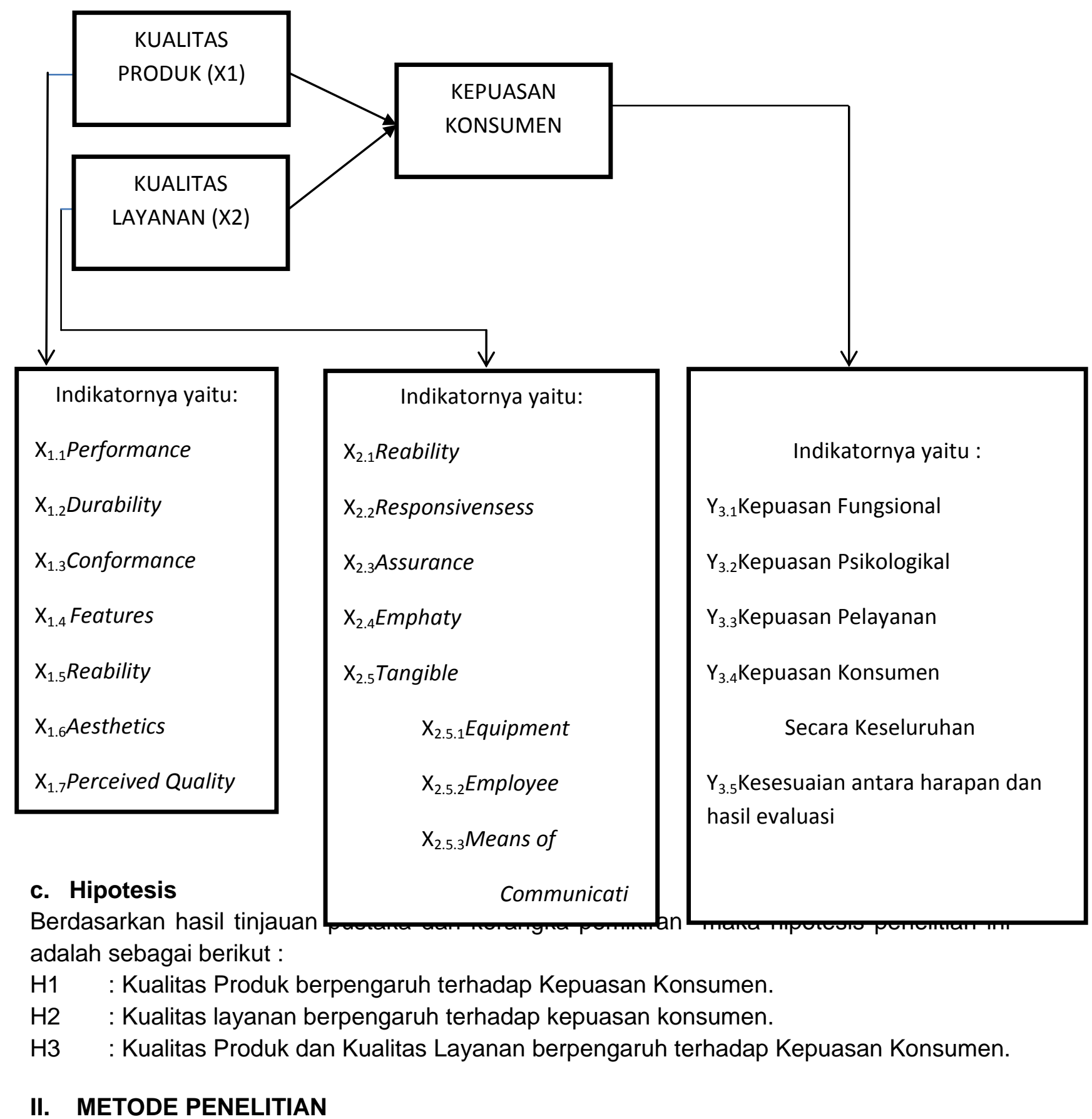

\section{a. Jenis Penelitian}

Berdasarkan metode yang digunakan penelitian ini menggunakan metode surve, mencari keterangan secara faktual, memperoleh fakta dari gejala yang dialakukan terhadap sampel atau populasi.

\section{b. Sumber Data}

1. Data primer, yaitu data yang dikumpulkan dan diperoleh langsung melalui pengisian oleh responden dalam penelitian ini adalah konsumen Restoran dalam penelitian ini adalah konsumen Restoran Iga Bakar Mas Sugiri Purwokerto. 
2. Data sekunder, yaitu data yag diperoleh dari studi pustaka yang berhubungan dengan masalah yang diteliti.

\section{c. Metode Pengumpula Data}

1. Kuisioner, yaitu dengan cara membagikan pertanyaan kepada responden untuk memperoleh informasi yang berkaitan dengan dan bermanfaat bagi penelitian.

2. Studi pustaka, yaitu dengan mempelajari dan menerapkan literatu-literatur yang berhubungan dengan penelitaian.

3. Wawancara, yaitu melakukan tanya jawab dengan pihak manajemen Restoran Iga Bakar Mas Giri dan responden untuk mendapatkan informasi yang berhubungan dengan penelitian.

\section{d. Populasi dan Sampel}

1. Polulasi adalah wilayah generalisasi yang terdiri atas objek dan subjek yang mempunyai kulaitas dan karakterisitk tertentu yang diterapkan oleh peneliti untuk dipelajari dan kemudian ditarik kesimpulan (Sugiyono, 2011). Populasi dalam penelitian ini adalah konsumen restauran Iga Bakar Mas GiriPurwokerto.

2. Sampel

Sampel adalah bagian dari jumlah dan karakterisitik yang dimiliki oleh populasi tersebut (Sugiyono, 2011). Pengambilan sampel dalam penelitian ini menggunakan metode Acidental Sampling. Untuk penelitian ini direncanakan menggunakan sampel / responden 100 sampel sebesar ini secara statistik ini merupakan ukuran besar karena diatas 30 responden.

\section{e. Teknik Accidental Sampling}

Merupakan teknik dalam memilih sampel, pemilih tidak memiliki pertimbangan lain kecuali berdasarkan kemudahan saja. Seseorang diambil sebagai sampel karena kebetulan sedang berada atau berjumoa ditempat pengambian sampel.

\section{f. Skala Likert}

Indikator-indikator vriabel tersebut diukur dengan menggunakan sekala likart lima jenjang, yaitu:

1. STS : Sangan Tidak Setuju

2. TS : Tidak Setuju

3. BS : Biasa Saja

4. S : Setuju

5. SS : Sangat Setuju

Untuk setiap pertanyaan yang diajukan, Sekor dari setiap pertanyaan yang di ajukan dijumlakan untuk menda[at sekoer gabungan. Nilai total untuk seluruh jawaban dihitung untuk setiap responden.

\section{g. Definisi Operasional}

Variabel-variabel yang digunakan dalam penelitian inii adalah sebagai berikut: 
1. Kuatilas Produk, yakni kemampuan suatu barang untuk memberikan hasil atau kinerja yang sesuai atau juga melebihi dari apa yang dinginkan konsumen Iga Bakar, Indikator - indikatornya adalah sebagai berikut:

a. Performence yaitu rasa yang enak berupa Kandungan Rempah dari Iga Bakar adalah kesesuaian rasa yang dirasakan oleh pelanggan karena bumbu rempah yaitu lada, ketumbar, bawang dan lainya yang terdapat pada Iga Bakar yang disajikan, keempukan daging Iga Bakar dan kelezatanya.

b. Durability yaitu daya tahan produk Iga Bakar apakah bisa bertahan lama untuk digunakan atau dikonsumsi.

c. Conformance yaitu sejauh mana karakteristik oprasi dasar dari sebuah produk Iga Bakar memenuhi sepesifikasi tertentu dari konsumen atau tidak ditemukan cacat pada produk.

d. Feature yaitu karakteristik produk Iga Bakar yang dirancang untuk menyempurnakan fungsi produk atau menambah ketertarikan konsumen terhadap Produk Iga Bakar.

e. Reability yaitu probabilitas bahwa produk Iga Bakar akan bekerja dengan memuaskan atau tidak dalam periode waktu tertentu, semakin kecl kemungkinan kerusakan maka produk Iga Bakar tersebut dapat diandalkan.

f. Aesthetics yaitu bagimana penampilan produk Iga Bakar dapat dilihat dari tampak, rasa, bau dan bentuk dari produk.

g. Precived Quality yaitu persepsi pelanggan terhadap produk Iga Bakar yang didapat dari harga, merk, periklanan, reputasi dan Negara Asal.

2. Kualitas layanan, yakni menurut Tjiptono (2005): "kualitas jasa atau pelayanan yang mendefinisikan sebagai kondisi dinamis yang berhubungan dengan produk, jasa,sumber daya manusia, proses, dan lingkungan yang memenuhi atau tidak melebihi harapan." Indikator-indikatornya adalah :

a. Reability (kehandalan) yaitu kemamouan pelayan restauran Iga Bakar Mas Giri untuk memberikan pelayanan yang dijanjikandengan segera, akurat dan memuaskan konsume.

b. Responsiveness (daya tangkap) yaitu kemapuan para pelayan dengan tanggapan yang baik dan berkesan.

c. Asurance yaitu kemampuan, kesopanan, dan sifat dipercaya yang dimiliki oleh para staf restauran Iga Bakar Mas Giri, bebas dari bahaya, ersiko dan keraguraguan dalam memberikan pelayanan.

d. Emphaty yaitu kemudahan dalam melakukan hubungan, komunikasi yang baik, perhatian pribadi, dan memahami kebutuhan konsumen pada restauran Iga Bakar Mas Giri.

e. Bangible yaitu fasilitas seperti tempat parkir, meja makan, ruang tunggu, toilet, mushola, kasir pada restauran Iga Bakar Mas Giri.

1. Equipment (perlengkapan) seperti tempat cuci tangan, alat untuk makan, tisu, hiburan, seperti live music atau karaoke pada restauran Iga Bakar Mas Giri.

2. Employe (oegawai) meliputi, pelayan atau pramusaji, kebersihan, admir, juru masak yang ada pada restauran Iga Bakar Mas Giri.

3. Mean of Comunication (sarana kominikasi) yaitu berupa Call Order yang dapat mempermudah konsumen melakukan pemesanan yang diantar kerumah tanpa harus datang langsung ke restauran Iga Bakar Mas Giri. 
3. Kepuasan konsumen, yakni kesesuaian antara harapan sebelum mengkonsumsi Iga Bakar dengan hasil evalluasi setelah mengkonsumsi Iga Bakar. Indikatorindikatornya adalah:

a. Kepuasan Fungsional yaitu Kepuasa dari Produk Iga Bakar pada restauran Iga Bakar Mas Giri Purwokerto yang mebuat perut kenyang setelah mengkonsumsi Iga Bakar dengan prosi pas.

b. Kepuasan Pesikologikal, hasil dari kepuasan dalam mengkonsumsi produk dan pelayanan di restauran Iga Bakar Mas Giri.

c. Kepuasan pelayanan, yaitu kepuasan yang diperoleh dari tempat parkir luas, tempat makan yang nyaman, sikap ramah pelayanan, dan penyajian yang cepat ada restauran Iga Bakar Mas Giri.

d. Kepuasan konsumen secara keseluruhan.

e. Kespuasan antara harapan dengan hasil evaluasi.

\section{HASIL DAN PEMBAHASAN}

\section{a. Respon Rate}

Peneliti membagi kuiioner sejumlah 120 eksemplar. Kuesioner kembali semua, yang dapat dianalisis adalah 108 exp, hal ini disebabkan 12 ex tidak lengkap (kuisioner kembali tidak sah). Dengan demikian respon rate sebanyak (108/120x100\% sama dengan 90\%). Berdasarkan tabel tersebut diketahui bahwa dari 108 orang Konsumen Iga Bakar Mas Giri Purwokerto mayoritas berusia 20-30 tahun sebanyak 60 orang atau 55,56\%. Untuk responden terbanyak adalah dari laki-laki yaitu 50 orang atau $46.30 \%$. sedangkan pekerjaan untuk responden terbesar adalah pelajar / mahasiswa yaitu 47 orang atau $43.52 \%$. mayoritas responden barasal dari mahasiswa, hal ini membuktiakan bahwa kualitas produk dan kualitas pelayanan mempengaruhi kepuasan konsumen pada restauran Iga Bakar Mas Giri adalah sebagian bersar pelajar / mahasiswa dan sebagian kecil dari para pegawai baik negeri maupun swasta.

Tingkat Pengembalian Kuesioner

\begin{tabular}{|c|c|c|c|}
\hline No. & Keterangan & Jumlah & Prosentase \% \\
\hline 1 & Kuesioner yang di bagikan & 120 & 100 \\
\hline 2 & Kuesioner kembai tidak sah & 12 & 10 \\
\hline 3 & Kuesioner kembali lengkap & 108 & 100 \\
\hline
\end{tabular}

\section{b. Deskripsi Responden}

Dari 108 responden dapat didudun deskripsi mengenai umur, jenis kelamin, dan pekerjaan sebagi berikut:

\begin{tabular}{|l|l|c|c|}
\hline No. & \multicolumn{1}{|c|}{ Keterangan } & Jumlah & Prosentase \% \\
\hline 1 & Umur ( tahun) & & \\
\hline & a. $<20$ & 14 & 12.96 \\
\hline
\end{tabular}




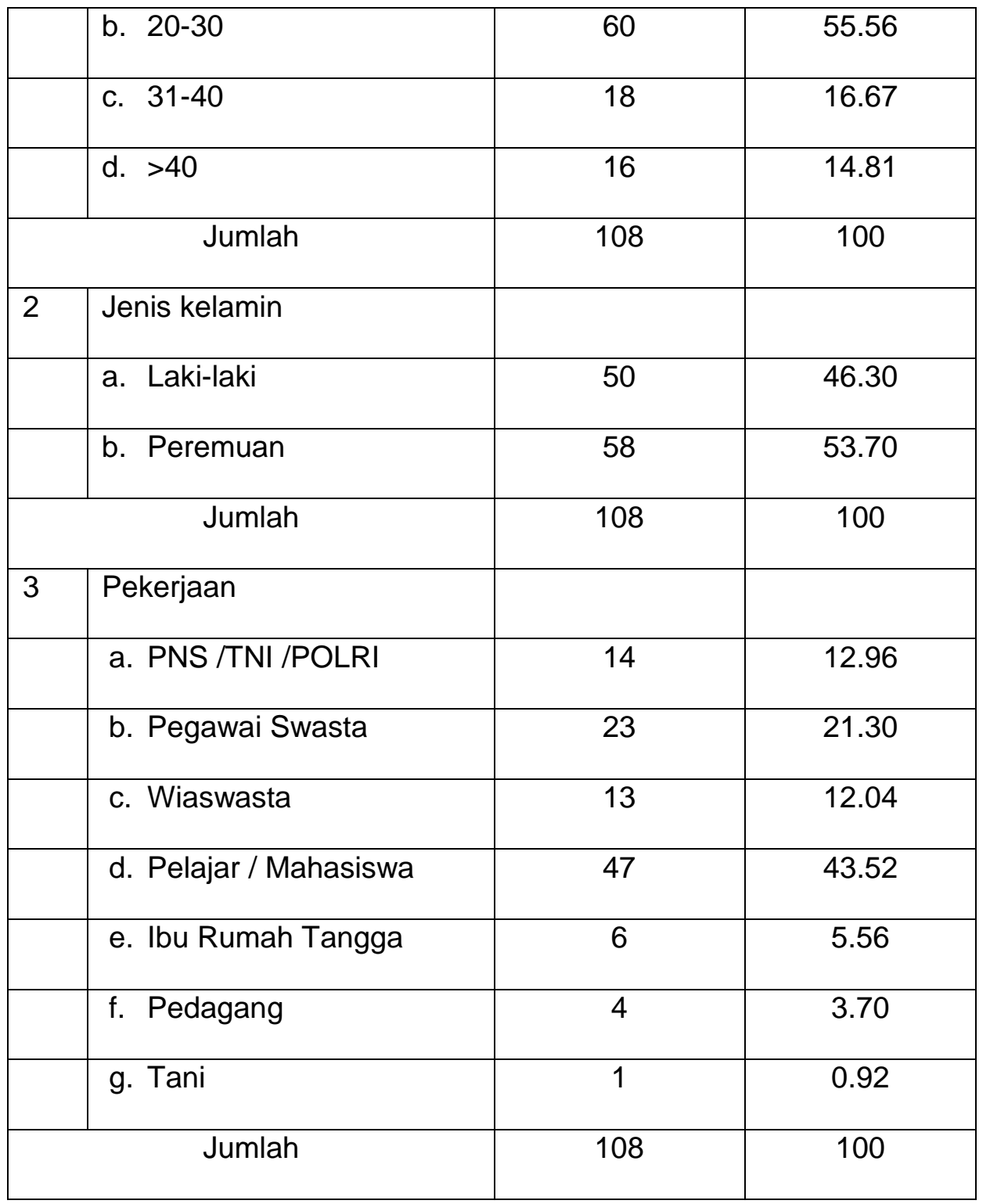

Berdasarkan tabel tersebut diatas bahwa dari 80 orang konsumen Iga Bakar Mas Giri Purwokerto mayoritas berusia 20-30 tahun sebanyak 60 orang atau 55.56\%. untuk responden terbanyak adalah dari laki-laki yaitu 50 orang, atau $46.30 \%$. sedangkan pekerjaan untuk respon responden adalah pelajar / mahasiswa, hal ini membiktikan bahwa kualitas produk dan kualitas layanan mempengaruhi kepuasan konsumen pada restauran Iga Bakar Mas Giri adalah sebagian besar pelajar / mahasiswa dan sebagian kecilnya adalah para pegawai baik negri maupun swasta.

\section{c. Uji Kualitas Data}

1. Uji Realibilitas

Uji realibilitas merupakan uji kehandalan yang bertujuan untuk mengetahui seberapa jauh alat ukur tersebut dapat diepercaya. Kehandalan berkaitan dengan seberapa jauh suatu alat ukur konsisten apabila pengukuran dilakukan secara beulang dengan sampel yang berbeda-beda. 
Nunnaly dalamGozali (2001). Kriteria pengujuan tes reliabilitas dapat menggunakan tabel kriteria indek koefisien reliabilias sebagai berikut:

\begin{tabular}{|c|c|}
\hline Interval & Kriteria \\
\hline$<0,200$ & Sangat Lemah \\
\hline $0,200-0,399$ & Rendah \\
\hline $0,400-0,599$ & Cukup \\
\hline $0,600-0,799$ & Tinggi \\
\hline $0,800-0,1000$ & Sangat tinggi \\
\hline
\end{tabular}

Berdasarkan hasil penelitian yang sudah diolah diperoleh koefisien reliabilitas dapat dilihat pada tabel

\section{Hasil Uji Reliabilitas}

\begin{tabular}{|l|c|c|c|}
\hline \multicolumn{1}{|c|}{ Variabel } & $\begin{array}{c}\text { Koefisien } \\
\text { reliabilitas }\end{array}$ & Keterangan & Reliabilitas \\
\hline Kualitas Produk & 0.807 & Sangat Tinggi & Reliable \\
\hline Kualitas Layanan & 0.981 & Sangat Tinggi & Reliable \\
\hline $\begin{array}{l}\text { Kepuasan } \\
\text { Konsumen }\end{array}$ & 0.837 & Sangat Tinggi & Reliable \\
\hline
\end{tabular}

Berdasarkan tabel seluruh variabel dikatakan reliable karena nilai koefisien reliabilitasnya diatas 0,60 (Nunnally dalam Gozali, 2011).

\section{Uji Validitas}

Uji validitas ini membandingkan nilai masing-masing item pertanyaan, masingmasing variabel melebihi nilai signifikansi maka pertanyaan tersebut tidak valid. Nilai ozalisignifikansi harus lebih kecil dari 0,05 maka item pertanyaan baru dikatakan valid. (Ghozali, 2001) nilai signifikannya dapat dilihat pada tabel:

\begin{tabular}{|l|c|c|c|}
\hline \multicolumn{1}{|c|}{ Item Pertanyaan } & Nilai Signifikan & Alpha & Keterangan \\
\hline Kualitas Produk 1 & 0.00 & 0.05 & Valid \\
Kualitas Produk 2 & 0.00 & 0.05 & Valid \\
Kualitas Produk 3 & 0.00 & 0.05 & Valid \\
Kualitas Produk 4 & 0.00 & 0.05 & Valid \\
Kualitas Produk 5 & 0.00 & 0.05 & Valid \\
Kualitas Produk 6 & 0.00 & 0.05 & Valid \\
Kualitas Produk 7 & 0.00 & 0.05 & Valid \\
Kualitas Layanan 1 & 0.00 & 0.05 & Valid \\
Kualitas Layanan 2 & 0.00 & 0.05 & Valid \\
Kualitas Layanan 3 & 0.00 & 0.05 & Valid \\
Kualitas Layanan 4 & 0.00 & 0.05 & Valid \\
Kualitas Layanan 5 & 0.00 & 0.05 & Valid \\
Kualitas Layanan 6 & 0.00 & 0.05 & Valid \\
Kualitas Layanan 7 & 0.00 & 0.05 & Valid \\
Kualitas Layanan 8 & 0.00 & 0.05 & Valid \\
\hline
\end{tabular}




\begin{tabular}{|l|l|l|l|}
\hline Kualitas Layanan 9 & 0.00 & 0.05 & Valid \\
Kepuasan Konsumen 1 & 0.00 & 0.05 & Valid \\
Kepuasan Konsumen 2 & 0.00 & 0.05 & Valid \\
Kepuasan Konsumen 3 & 0.00 & 0.05 & Valid \\
Kepuasan Konsumen 4 & 0.00 & 0.05 & Valid \\
Kepuasan Konsumen 5 & 0.00 & 0.05 & Valid \\
\hline
\end{tabular}

Berdasarkan tabel tersebut terlihat bahwa semua item pertanyaan dapat dikatakan valid karena semua nilai signifikasi kurang dari 0,05 dan didapat hasil semua item pertanyaan valid.

\section{c. Uji Asumsi Klasik}

1. Uji Normalitas

Untuk menguji apakah dalam model regresi, variabel pengganggu atau residual memiliki distribusi normal. Untuk itu dilakukan uji normalitas dengan menggunakan normal P-Plot, analisis grafik dan uji statistik.

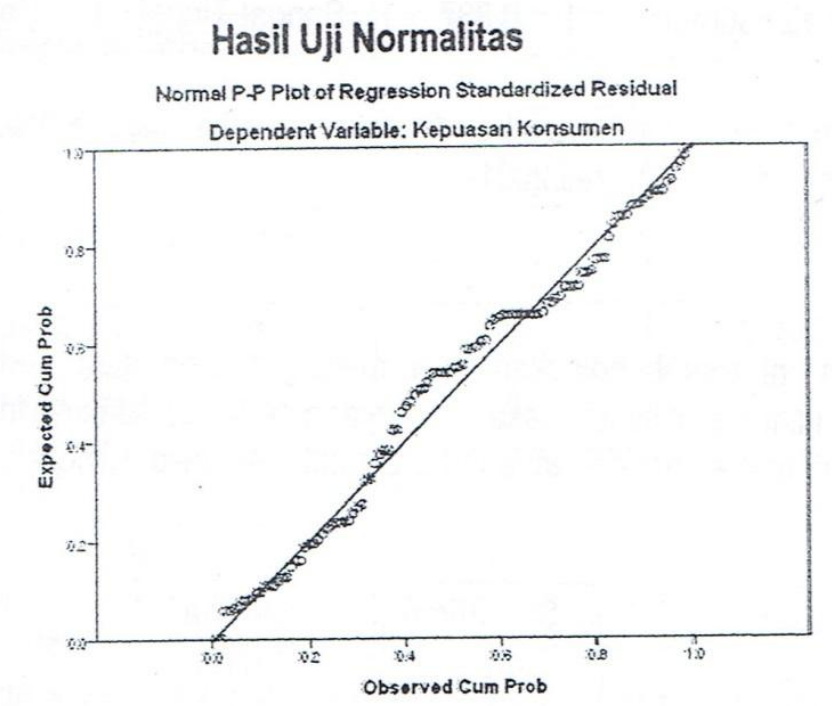

Dengan melihat grafik normal P-Plot tersebut dapat disimpulkan bahwa grafik normal plot terlihat titik-titik berada disekitar garis diagonal, dengan demikian dapat disimpulkan bahwa data telah terdistribusi normal (Gozali,2005).

Uji statistik lainnya yang digunakan untuk menguji normalitas residual adalah dengan uji statistik non-parametrik kolmogrov-Smimov (K-S). dilakukan dengan membuat hipotesis :

HO : Data residual berdistribusi normal.

HA : Data residual tidak berdistribusi normal. 
One- Sample Kolmogorov-Smirnov Test

\begin{tabular}{|l|r|}
\hline & Ustandarized residual \\
\hline $\mathrm{N}$ & 108 \\
Normal Mean & .0000000 \\
Parameter ${ }^{\text {a,b }}$ Std.Deviation & .33384220 \\
Most Extrem Absolute & .085 \\
Differences Positive & .051 \\
& Negative \\
Kolmogorov - Semirnov Z & 085 \\
Asymp.Sig. (2-tailed) & .885 \\
\hline
\end{tabular}

Berdasarkan uji normalitas, dapat dilihat bahwa nilai Kolmovgorov-Smirnov adalah sebesar 0.885 dan Asymp. Sig.(2-tailed) sebesar 0.414 lebih besar dari a (0.05) maka dapat disimpulkan bahwa data terdistribusi normal.

2. Uji Multikolinearitas

Model regresi yang baik seharusnya tidak terjadi korelasi diantara variabel bebas. Uji Multikolinearitas dapat juga dilihat dari nilai toleranci dan Varian Inflation factor (VIF). Nilai cut off yang umum digunakan adalah nilai toleranci $>0.10$ atau sama dengan nilai VIF $<10$ berarti tidak ada multikolinearitas antar variabel bebas dalam model regresi (Ghozali, 2005).

Hasil Uji Multikolinearitas Coefficients ${ }^{a}$

\begin{tabular}{|c|c|c|c|c|c|c|c|}
\hline \multirow[t]{2}{*}{ Model } & \multicolumn{2}{|c|}{$\begin{array}{c}\text { Unstandardiz } \\
\text { ed } \\
\text { Coefficients }\end{array}$} & \multirow{2}{*}{$\begin{array}{c}\text { Standardize } \\
\text { d } \\
\text { Coefficients }\end{array}$} & \multirow[t]{2}{*}{$t$} & \multirow[t]{2}{*}{ Sig. } & \multicolumn{2}{|c|}{$\begin{array}{c}\text { Collinearity } \\
\text { Statistics }\end{array}$} \\
\hline & $B$ & $\begin{array}{l}\text { Std. } \\
\text { Error }\end{array}$ & & & & $\begin{array}{l}\text { Toler } \\
\text { ance }\end{array}$ & VIF \\
\hline $\begin{array}{l}1 \\
\text { (constan }\end{array}$ & .272 & .279 & & .977 & .331 & & \\
\hline $\begin{array}{l}\text { t) } \\
\text { kualitas }\end{array}$ & .384 & .074 & .380 & 5.162 & .000 & .719 & $\begin{array}{l}1.39 \\
1\end{array}$ \\
\hline $\begin{array}{l}\text { Produk } \\
\text { Kualitas } \\
\text { layanan }\end{array}$ & .514 & .077 & .077 & 6.725 & .000 & .719 & $\begin{array}{l}1.39 \\
1\end{array}$ \\
\hline
\end{tabular}

a.Dependent Variabel: Kepuasan Konsumen

Berdasarkan hasil uji multikolinearitas diketahui bahwa nilai VIF semua kurang dari 10 maka dapat disimpulkan bahwa model regresi sudah terbebas dari multikolinearita (Ghozali, 2005).

3. Uji Heteroskedastisitas

Uji Heteroskedastisitas bertujuan untuk menguji apakah dalam model regresi terjadi ketidaksamaan varian dari residual satun pengamatan ke pengamatan lain yang tetap. Deteksi terhadap heteroskedastisitas dapat dilakukan dengan melihat ada/tidaknya pola tertentu pada grafik scatterplot. Sebagai berikut: 


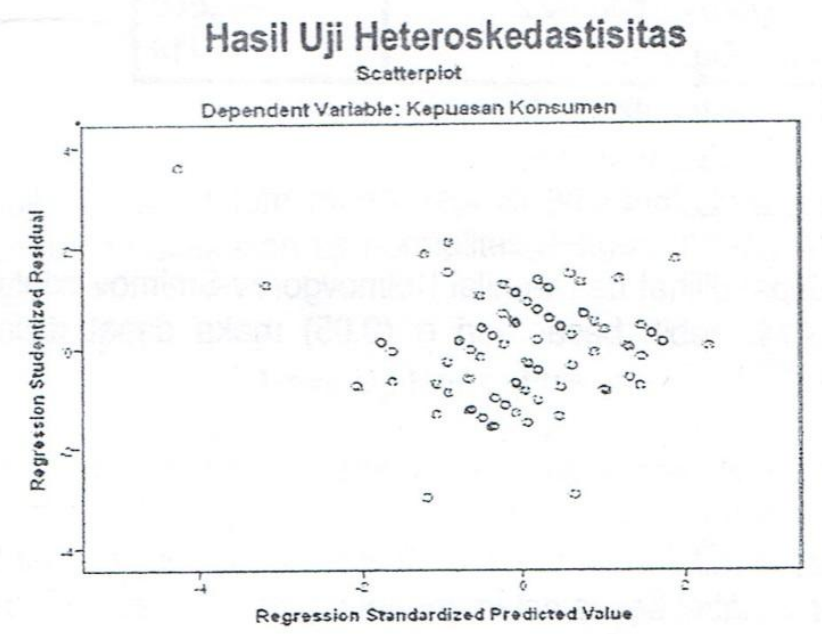

Berdasarkan dari grafik scatterplots terlihat titik-titik menyebar secara acak (random) baik diatas maupun dibawah angka 0 pada sumbu Y. Hal ini dapat disimpulkan bahwa tidak terjadi heteroskedastisitas pada model regresi dan regresi mempunyai syarat BLUE (Best Unbias Esitimator) (Ghozali, 2005).

\section{d. Analisis Linear Berganda}

Untuk mengetahui pengaruh variabel kualitas produk dan kualitas layanan terhadap kepuasan konsumen digunakan alat analisis regresi linier berganda. Hasil uji regresi linier berganda dapat dilihat Tabel 4.6. Besarnya tabel tersebut dapat disusun persamaan linier berganda sebai berikut :

$$
\mathrm{Y}=0,272+0,384 \mathrm{X} 1+0.514 \mathrm{X} 2
$$

Berdasarkan persamaan regresi tersebut dapat diketahui bahwa jika variabel independen tidak berubah maka kepuasan konsumen sebesar 0.272 satuan. Sedangkan koefisien regresi variabel kualitas produk sebesar 0.384 satuan menyatakan bahwa setiap terjadi peningkatan kualitas produk satu satuan, maka akan terjadi peningkatan kepuasan konsumen sebesar 0.384 satuan, jika variabel independen yang lain tidak berubah. Koefisien regresi variabel kualitas layanan sebesar 0.541 satuan menyatakan bahwa setiap terjadi peningkatan kualitas layanan satu satuan maka akan terjadi peningkatan kepuasan konsumen sebesar 0.541 satuan jika variabel independen yang lain tidak berubah.

\section{e. Koefisien Determinan $\left(R^{2}\right)$}

Untuk dapat mengetahui sampai seberapa besar prosentasi variasi variabel bebas pada model dapat diterangkan oleh variabel terikat, maka digunakan koefisien determinasi (adjusted $\mathrm{R}^{2}$ ) (Gujarati, 2003). Hasil uji adjusted $\mathrm{R}^{2}$ dapat dilihat tabel 4.7 Nilai adjusted $\mathrm{R}^{2}$ sebesar $0.582(58.2 \%)$ hal ini berarti variabel kepuasan konsumen dijelaskan oleh kualitas produk dan kualitas layanan sebesar $58.2 \%$ sedangkan sisanya $41.8 \%$ depengaruhi oleh faktor lain yang tidak diteliti dalam penelitian ini. Sedangkan besarnya koefisien korelasi antara kualitas produk dan kualitas layanan dengan kepuasan konsumen adalah sebesar 0.768. ini menunjukan korelasi/hubungan yang tinggi. Data koefisien nilai korelasi menurut Young (1982) (dalam tim penyusun PAS, 2011) adalah sebagai berikut : 
- 0.70 s.d 1.00 (nilai absolut) menunjukan adanya tingkat hubungan yang tinggi.

- 0.340 s.d $<0.70$ (nilai absolut) menunjukan adanya tingkat hubungan yang substansial.

- $0.20 \mathrm{~s} . \mathrm{d}<0.40$ (nilai absolut) menunjukan adanya tingkat hubungan yang rendah.

- $<0.20$ (nilai absolut) menunjukan tidak adanya hubungan.

\section{f. Pegujian Hipotesis}

\section{Pengujian Hipotesis Pertama}

Berdasarkan Tabel 4.6 diperoleh nilai signifikansi variabel kualitas produk sebesar 0.00 kurang dari 0.05 . dengan nilai thitung sebesar 5.162 lebih dari t tabel sebesar 1.65950 pada tingkat signifikan $5 \%$ dengan (df) $n-k-1=105$, uji dilakukan dua sisi, artinya kualitas produk berpengaruh terhadap kepuasan konsumen. Dengan demikian hipotesis pertama yang diajukan diterima.

2. Pengujian Hipotesis Kedua

Berdasarkan tabel 4.6 diperoleh nilai signifikansi variabel kualitas layanan sebesar 0.00 kurang dari 0.05 . dengan nilai thitung sebesar 6.7251 lebih dari ttabel sebesar 1.65950 pada tingkat signifikan $5 \%$ dengan (df) $n-k-1=105$, uji dilakukan dua sisi, artinya kualitas layanan berpegaruh terhadap kepuasan konsumen. Dengan demikian hipotesis kedua yang diajukan diterima.

\section{g. Pengujian Hipotesis Ketiga}

Untuk mengetahui pengaruh kualitas produk dan kualitas layanan terhadap kepuasan konsumen pada restauran iga bakar mas giri purwokerto dilakukan dengan menggunakan uji F. Hasil uji F dapat dilihat dalam Tabel 4.8. Berdasarkan tabel 4.8 dapat dilihat nilai signifikan dari hasil uji $F$ sebesar 0.000 yang berarti kurang dari 0.05 , dengan nilai Fhitung sebesar 75.555 lebih besar dari Ftabel 3.08 maka dapat disimpulkan bahwa variabel independen kualitas produk dan kualitas layanan mempengaruhi variabel kepuasan konsumen.

\section{PEMBAHASAN}

Kepuasan konsumen merupakan harapan bagi manajemen, dalam hal ini manajemen Iga Bakar Mas Giri yang mengharapkan setiap konsumen yang mengkonsumsi Iga Bakar akan puas karena Iga bakar yang disajikan memenuhi harapan konsumen. Pengaruh yang cukup signifikan ditunjukan dari nilai adjusted $\mathrm{R}^{2}$ sebesar $58 \%$.

Kualitas produk secara parsial dengan nilai signifikansi sebesar 0.000 kurang dari 0,05 dengan nilai t hitung sebesar 5.162 lebih dari t tabel 1.65950 pada nilai tingkat signifikansi $5 \%$ dengan (df) $n-k-1$ berpengaruh terhadap kepuasan konsumen. Sedangkan untuk kualitas layanan secara parsial dengan nilai signifikansi 0.000 kurang dari 0.05 dengan nilai $t$ hitung sebesar 6.7251 lebih dari t tabel 1.65950 pada nilai tingkat signifikansi 5\% dengan (df) n-k-1 berpengaruh terhadap kepuasan konsumen.

Hasil penelitian memperoleh bukti bahwa kualitas produk, kualitas layanan secara simultan dengan signifikansi 0.000 yang berarti kurang dari 0.05 dengan nilai Fhitung 75.555 lebih besar dari Ftabel 3.08 berpengaruh terhadap kepuasan konsumen. Hal ini 
diduga dengan kualitas produk yang baik akan meningkatkan kepuasan konsumen. Dengan kepuasan konsumen yang baik restauran akan semakin berkembang dan maju.

Penelitian ini sejalan dengan penelitian yang dilakukan oleh Hidayat (2009) tentang pengaruh kualitas layanan, kualitas produk dan nilai nasabah terhadap kepuasan dan loyalitas nasabah Bank Mandiri. Penelitian ini menemukan bukti bahwa kualitas produk dan kualitas layanan berpengaruh signifikan terhadap kepuasan Nasabah atau konsumen yang sejalan dalam penelitian yang dilakukan pada masing-masing subjek dan objek penelitian.

\section{KESIMPULAN DAN SARAN}

\section{a. Kesimpulan}

Berdasarkan analisis yang telah dilakukan, maka ditarik beberapa kesimpulan, antara lain :

1. Kualitas produk berpengaruh terhadap kepuasan konsumen, hal ini dibuktikan dengan nilai signifikan sebesar 0.000 kurang dari 0.05 .

2. Kualitas layanan berpengaruh terhadap kepuasan konsumen, hal ini ditunjukan dengan nilai signifikan sebesar 0.000 kurang dari 0.05 .

3. Kualitas produk, kualitas layanan secara simultan berpengaruh terhadap kinerja karyawan. Hal ini ditunjukan dengan nilai signifikan sebesar 0.000 kurang dari 0.05 .

\section{b. Saran}

1. Bagi manajemen Iga Bakar Mas Giri Purwokerto, hendaknya lebih meningkatkan kualitas produk dengan memilih bahan-bahan baku yang berkualitas baik dari daging iga, bahan rempah-rempah untuk membuat bumbu, menambah porsi nasi agar konsumen dapat merasa kenyang pada satu porsi iga bakar dan pada kualitas layanan, lebih meningkatkan skill secara teknis, respect pada kebersihan meja makan dan lantai agar konsumen bisa merasa nyaman.

2. Bagi penelitian yang akan datang hendaknya menambah variabel penelitian yang berpengaruh terhadap kepuasan konsumen, misalnya loyalitas Pelanggan.

\section{DAFTAR PUSTAKA}

Agyl, Satrio Hutomo. 2009. Pengaruh kualitas produk dan Tingkat kepuasan Konsumen Terhadap Loyalitas Pelanggan Pada Produk makanan Tela Krez Cabang Bekasi.

Assauri, Sofyan. 2003. "Costumer Service Yang Baik Landasan Pencapaian Costumer Satisfactio." Manajemen Usahawan Indonesi." No. 01, TH. XXXII, Januari.

Engel, James F., et.al. 1994. Costumer Behavior. Diterjemahkan oleh F.X Budiyanto, Perilaku Konsumen. Edisi keenam. Cetakan pertama. Jilid ii. Jakarta:Binarupa Aksara.

Fornell, C 1992. A. National Customer Satisfaction Barometer, The Swedish Experince, Journal of Marketing. Vol 56, Januari, pp 6-21. 
Frucott, V. dan W. T. Shearon. 1991. "Budgetary participation, Locus Of Control \& Mexican managerial perfomence and job satisfaction”. The Accounting Review. Vol. 65.

Ghozali, Imam. 2005. Analisis Multivariate Aplikasi dengan program SPSS. UNDIP Semarang

Gujarati, Damodar N. 1995. Ekonometrika Dasar. Penerbit Erlangga, Jakarta.

Damodar N. 2003. Basic Ekonometrics Fourth Edition Internasional Edition. McGraw-Hill Singapore.

Hidayat, Rachmad, 2009. Pengaruh Kualitas Layanan, Kualitas Produk dan Nilai Nasabah Terhadap Kepuasan dan Loyalitas Nasabah Bank Mandiri. Madura.

Irawan, H. 2002. 10 Prinsip Kepuasan Pelanggan. Jakarta. PT Elex Media Komputindo.

H. 2007. 10 Prinsip Kepuasan Pelanggan. PT Elex Media Komputindo. Jakarta.

Juwandi, Hendy Irawan. 2004. Kepuasan pelayanan jasa. Erlangga. Jakarta.

Kotler, Philip, 1995, Manajemen Pemasaran, Jakarta. Penerbit Erlangga.

P. 1997. Manajemen Pemasaran, Analisis, Perencanaan, Implementasi, dan Kontrol. Terjemahan. PT Prehalindo. Jakarta.

P. 2000. Manajemen Pemasaran. Terjemahan. Jilid I. Edisi Milenium. PT Prehalindo. Jakarta.

, Philip dan Amstrong, 2004. Prinsip-prinsip pemasaran edisi sepuluh jilid 1, Jakarta. PT. Indeks Kelompok.

Karina, Kartika Sari. 2009. Analisis Kepuasan Konsumen Restauran Ayam Geprek Istimewa Bogor

Philip dan Gary Amstrong, 1997, Prinsip-Prinsip Pemasaran, Erlangga, Jakarta.

Mullins, John W, Orville C, Walker Jr, Jean Claude Larreche, and Harper W. Boyd. 2005. Markerting Manajemen: A Strategic Decision Maker Approach. New York : The Megraw-Hill Companies.

Nunnaly dalam Ghozali, Imam. 2001. Analisis Multivariate dengan program SPSS. Badan Penerbit Universitas Diponegoro, Semarang.

PTA, Semester, 2007/2008. Materi ke 4, statistik 1, teknik sampling.

Ridwan. 2005. Belajar Mudah Penelitian Untuk Guru, Karyawan dan Peneliti Pemula, Bandung : Alfabeta.

Sugiyono. 2001. Metode Penelitian Administrasi. Bandung: Alfabeta.

, 2010. Metode Penelitian Kuantitatif Kualitatif dan R\&D, Penerbit ALFABETA.

, 2011. Statistika untuk Penelitian. Bandung: Alfabeta. 
Sumarwan, Ujang, 2004. Perilaku Konsumen, Ghalia Indonesia, Bogor Selatan.

Tim Penyusun PAS. 2011. Materi Pelatihan Analisis Statistik. Universitas Muhammadiyah Purwokerto.

Tjiptono, Fandy. 2005. Pemasaran Jasa. Edisi Pertama. Malang: Bayumedia

Torsina, M. 2000. Usaha Restoran yang Sukses. Jakarta: PT Buana IImu Populer Kelompok Gramedia.

Triyani, 2009. Pengaruh Sikap Konsumen terhadap Keputuan Pembelian Handphone Nokia, Malang.

www.scribd.com/doc/92590343/indikator-Kepuasan

Zeithaml, V. et. al. 1990. Delivering Quality. $5^{\text {th }}$ Edition, Free Press A Division of Macmilan Inc.

Zeithaml et. al. 1996. Measuring the Quality of relationship in customer service : An emprical study. European. Journal Of Marketing. 